HanNa Gosk

Uniwersytet Warszawski

\title{
Zjadacze łabędzi. Obcość relatywna w doświadczeniu polskiej migracji ekonomicznej do Wielkiej Brytanii po roku 2004
}

\author{
[...] słodycz / nieskończonej mnogości \\ uwarunkowań, oddech jako zdolność do realizacji \\ tego, co człowiek zamierza [...] jesteśs / spragniony, \\ ale nie ustajesz $w$ wysiłkach, twój smak jest / \\ spaczony, ale $w$ dalszym ciagu łakniesz powietrza \\ $[\ldots]$
}

(Kornhauser 1978: 2)

Buty nie sa brudne same w sobie, ale brudne jest stawianie ich na stole w jadalni [...] rzeczy z zewnątrz we wnętrzu, rzeczy $z$ dołu na górze [...]

(Douglas 2007: 77)

Julian Kornhauser opublikował tomik poezji zatytułowany Zjadacze kartofli, z którego pochodzi pierwsze motto tego tekstu, w roku 1978, gdy przeciętny obywatel Polski Ludowej nie miał możliwości zarobkowego wyjazdu zagranicę. Poeta, wypełniając założenia programowe Nowej Fali, wyłożone w napisanej wspólnie z Adamem Zagajewskim książce Świat nieprzedstawiony (1974), starał się zaprezentować kształt tego, co pomijał dyskurs dominujący tamtego czasu historycznego, a więc m.in. świadomość uwarunkowań ograniczających wolność ludzkich wyborów życiowych i pragnienie tej wolności, nawet jeśli jej wyobrażenie bywało wielce niedoskonałe. Bohaterów swoich wierszy (z którymi zapewne się utożsamiał), nieustających w wysiłkach, by mimo barier realizować zamierzenia, nazwał „zjadaczami kartofli”, podkreślając tą niewyszukaną 
metaforą zgrzebność, przeciętność, szarość codzienności, w której, jak pisał nie bez gorzkiej ironii: „Brzuch [od tych kartofli - H.G.] jest może za ciężki, ale / jaka jasność umysłu!” (Kornhauser 1978: 3).

Kilka dekad później „zjadacze kartofli”, realizujący na swój sposób wyobrażenie o wolności i prawie wyboru lepszego życia, mieli się zamienić w „łabędziożerców”. Oto w 2006 roku lokalna gazeta z Manchesteru zamieściła taką (nieneutralną w swoich znaczeniach) informację: „W naszej okolicy znikają te piękne białe ptaki. Mieszkańcy uważają, że zjadają je polscy imigranci. Czy to prawda, że łabędź z ziemniakami to polskie tradycyjne danie?” (Winnicka 2014: 197).

A teraz, tytułem wprowadzenia, słowo o sensie drugiego motta wywodu spostrzeżenia antropolożki Mary Douglas o „brudzie” rozumianym szeroko, jako coś na kształt zakłócenia akceptowanych przez ogół porządków i klasyfikacji. Tam, gdzie zauważa się zakłócenie, istnieje też system wyraźnie przez nie podważany. Naruszenie systemu wywołuje impulsy, które mają przywrócić porządek, ponieważ (po/u)twierdza jego istnienie, lub zainicjować nową organizację otoczenia. W tej perspektywie można spojrzeć na gromadne pojawienie się w Anglii polskich migrantów ${ }^{1}$ zarobkowych w pierwszych latach XXI wieku, mając na uwadze frazę przywołaną w motcie: „Buty nie są brudne same $\mathrm{w}$ sobie, ale brudne jest stawianie ich na stole w jadalni [...] rzeczy z zewnątrz we wnętrzu” (Douglas 2007: 77, wyróż. - H.G.). (Tak, jak czynili to zapewne przeciwnicy ich obecności na Wyspach, gdy posługiwali się m.in. argumentami antyimigranckimi w batalii o wyjście Wielkiej Brytanii z Unii Europejskiej.)

Należy podkreślić, iż takie podejście implikuje dwie okoliczności: zbiór uporządkowanych związków i naruszenie ich ładu. Ukazanie relacji: naruszenie - system to opowieść o jednym i drugim oraz o samym procesie zakłócania; tu - opowieść o pojawieniu się polskiego Swojaka w obcym dlań systemie cywilizacyjno-kulturowym Wysp Brytyjskich, a więc opowieść o zewnętrzu i wnętrzu, o migrantach i gospodarzach terenu wzajemnie się obserwujących oraz o obustronnym doświadczaniu tego spotkania. Po wejściu Polski do Unii Europejskiej w 2004 roku polski Swojak (przeciętny obywatel, uosabiający polską wersję normy cywilizacyjno-kulturowej, która wyraźnie separuje Swoich od Obcych), często mieszkaniec niewielkiego miasta lub wsi (choć nie tylko), miał możliwość wyjechania na Wyspy w celu podjęcia pracy, poprawienia własnej sytuacji materialnej, zbliżenia się do realizacji marzeń o lepszym życiu.

1 W odniesieniu do osób decydujących się na wyjazd z kraju i poszukiwania pracy za granicą w celu poprawienia własnej sytuacji materialnej używam nazwy „migranci”, podobnie jak autorzy omówień literackich śladów polskiej migracji zarobkowej na Zachód po roku 2004, zamieszczonych w poświęconym tej problematyce numerze „Tekstów Drugich” z 2016 roku (nr 3: „Literatura migracyjna”). 
W tym wywodzie interesują mnie nieoczywiste na pierwszy rzut oka aspekty sytuacji, w której po wyjeździe z kraju ów Swojak zajął, jako migrant, pozycję Obcego i musiał się odnaleźć w relacji do brytyjskich Swojaków, a więc źródła normy, wobec której, jako przybysz, sytuował się na zewnątrz. Stawiam tezę, iż aporetyczność całej sytuacji polegała na tym, że miał on do dyspozycji instrumenty mało przydatne do wypracowania satysfakcjonującej obie strony relacji $\mathrm{z}$ gospodarzami Wysp, a może nawet znacznie utrudniające to zadanie. Były to bowiem głównie takie instrumenty, które - uwewnętrzniona przezeń, a powstała w innych warunkach - polska norma aktualizowała w relacji z Obcym. Jak można było nimi się posłużyć, gdy samemu stało się Obcym, a więc podatnym na posądzenia o niewystępujące w danym otoczeniu zachowania - niezrozumiałe, zadziwiające, egzotyczne dla brytyjskich Swojaków? Przerysowany wizerunek „zjadacza łabędzi” kondensował w sobie właśnie te cechy.

Nie wszyscy Brytyjczycy, ale brytyjscy zwolennicy odcięcia napływu taniej siły roboczej z Europy Środkowo-Wschodniej (bo na niej skoncentruję uwagę, a nie na wysoko wykwalifikowanych specjalistach, którym łatwiej udało się zaaklimatyzować w Wielkiej Brytanii) szybko zinstrumentalizowali w populistycznych wystąpieniach zjawiska zrodzone z podziałów cywilizacyjno-kulturowych, które ujawniały się przy okazji spotkania przedstawicieli społeczeństw europejskich o odmiennych, wyraźnie ukształtowanych (a dodatkowo wewnętrznie zróżnicowanych) tożsamościach zbiorowych, nawet jeśli ich nosiciele nie byli w stanie w życiu codziennym własnej tożsamości sproblematyzować, a jedynie intuicyjnie czy mimowiednie dawali jej wyraz.

By uwyraźnić paradoksy, z którymi przyszło zmierzyć się polskim Swojakom w spotkaniu z brytyjskimi Swojakami, a które (zależnie od przyjętej perspektywy) można też opowiedzieć jako spotkanie dwu różnych Obcych, w tym wywodzie zajmuję się okolicznościami symptomatycznymi, które pojawiły się w przykładowo wybranych tekstach reportażowych, z pełną świadomością, że jak zostało powiedziane - ani wszyscy Brytyjczycy nie okazali się przeciwnikami napływu migrantów zarobkowych z Europy kontynentalnej, ani też wszyscy polscy migranci nie zaznali samych złych doświadczeń po przybyciu na Wyspy.

Moim rozważaniom towarzyszą wypowiedzi bohaterów reportaży Ewy Winnickiej, polskich migrantów zarobkowych na Wyspach Brytyjskich w drugiej dekadzie xxı wieku, zrelacjonowane zunifikowanym językiem autorki, choć gramatycznie zachowujące kształt opowieści kolejnych osób na temat ich własnych doświadczeń z pobytu i pracy w Zjednoczonym Królestwie (Winnicka 2014: 
7-293). Nie zajmuje mnie analiza sztuki reportażu Winnickiej. Nie odnoszę się do tez autorki. Nie oceniam słuszności (lub nie) autoanaliz jej interlokutorów. Zebrane przez Winnicką relacje uznaję za swego rodzaju świadectwo - testimonium $^{2}$. Wydaje się, że jeden tom reporterskich rozmów to ani za mało, ani za dużo, raczej w sam raz, by potraktować zebrany w nim materiał na prawach case study. W tomie znalazły się bowiem symptomatyczne przypadki migranckich losów, które zarysowują ramy mieszczące wiele innych wariantów podobnych historii, po pewnym czasie użyte przez zwolenników brexitu jako jeden $\mathrm{z}$ argumentów przeciw obecności Wielkiej Brytanii w UE.

Dla mnie jednak to przede wszystkim opowieści Swojaka, który - znalazłszy się w sytuacji Obcego - zdaje relację ze swoich doznań i obserwacji. Skoro tak, to wpisuje się on w warunki, w których „Obcy-narrator nie uczestniczy, a jedynie obserwuje. [...] Dopóki obserwuje, nie może być włączony do wspólnoty" (Pajor 1999: 170). I tu powstaje problem dotyczący prób odnalezienia się takiego Swojaka w roli Obcego. Prezentacja aporii owej sytuacji stanowi cel mojego wywodu. Problem, o którym mowa, sygnalizują wstępnie dwa zestawy kluczowych słów użytych w wypowiedziach na temat relacji: polscy Swojacy zamienieni na Wyspach w Obcych vs. Brytyjczycy, dla migrantów Obcy, a jednocześnie Swojacy u siebie:

1. JA/MY polskiego migranta wobec $\mathrm{NICH}$, brytyjskich gospodarzy Wysp: niewidzialny, kanciasty, nieatrakcyjność, kompleksy, nieprzebojowość, półzwierzak, półżycie, samotność, ambicje zawodowe, bluzg, „chłopski rozum”, podspołeczeństwo, dziwność, przetrwać, lawirować, system, kod kulturowy;

2. ONI, Angole, według NAS, polskich przybyszów: odruchy ludzkie (ich brak), nienarzekanie, respekt dla otoczenia, dystans, dziwność, cywilizowanie (nas).

W obu zestawach powtarza się słowo „dziwność” (my dziwni dla nich, oni dla nas) wprost sygnalizujące istnienie różnicy kulturowej. Mniej lub bardziej udane próby uporania się z tą różnicą prowadzą do ukonstytuowania hybrydycznej tożsamości migranta. Jak pisze Tomasz Dobrogoszcz:

2 Testimonium rozumiem tu w kategoriach świadectwa, choć należy pamiętać, iż zostało ono w jakimś sensie przykrojone przez autorkę reportaży do potrzeb publikacji w takim a nie innym tomie. Świadectwo (łac. testimonium) to odmiana narracji występująca we współczesnych subaltern studies, poświęconych badaniu doświadczenia grup wcześniej podporządkowanych, marginalizowanych i poddanych opresji przez dysponentów władzy. Testimonium zrywa z rozdziałem między historią i literaturą, by pomóc w zakomunikowaniu doznań opresjonowanych ich własnym językiem (zapis reportażowy $\mathrm{z}$ definicji sytuuje się między historią i literaturą). 
Różnice między polską diasporą a społeczeństwem brytyjskim, uwypuklone przez stereotypy, są przejawem rozbieżności kulturowych między narodami. Jednym z trudniejszych etapów procesu tworzenia się hybrydycznej tożsamości migrantów jest akceptacja tych odmienności (Dobrogoszcz 2016: 51).

Należy zwrócić uwagę na negatywne pole semantyczne, w którym wypowiedzi interlokutorów Winnickiej sytuują Ja migranta. To podmiot wycofujący się, słaby, zdany na siebie i swoje kompleksy, osuwający się w hierarchii społecznej, żyjący na granicy (nie)widzialności. Takie Ja postrzega Onych, gospodarzy terenu, jako dobrze odnajdujących się w otoczeniu, szanujących je, dbających o nie i o siebie, nawet jeśli byłaby to troska fasadowa, bowiem Anglicy, według Polaków, nie okazują emocji. Owo Ja intuicyjnie odczuwa wyższościowy stosunek Brytyjczyków do przybyszów z Europy Środkowo-Wschodniej, których - jak się uważa na Wyspach - należałoby „ucywilizować”, by przestali razić prymitywizmem.

Polski Swojak czuje się więc dziwnie jako członek swoistego podspołeczeństwa. Ma własne ambicje, uruchamia „chłopski rozum”, czasem na dokuczliwą sytuację reaguje bluzgiem, a by przetrwać (jest przecież białym Europejczykiem, o czym pamięta), szuka w brytyjskim otoczeniu "gorszych" i znajduje ich wśród kolorowych mieszkańców Wysp. Uczy się lawirować, gdy dostrzega ramy systemu społeczno-kulturowego, na zewnątrz których sytuuje go kondycja migranta. Nawet jeśli nie potrafi tego nazwać, zaczyna odczuwać moc stanowiąco-wykluczającą owego systemu.

Winnicka zatytułowała swój zbiór relacji migrantów zarobkowych Angole. To lekceważąca nazwa nadawana mieszkańcom Wysp Brytyjskich przez niechętnych im nie-Brytyjczyków. W książce odnosi się jednak w pierwszym rzędzie do przybyłych na Wyspy Polaków oraz ich planu „skolonizowania”, wzięcia szturmem nowego terenu do życia, jak to w ironicznej notatce otwierającej tom ujmuje autorka. Tyle że opowieść o pojawieniu się polskiej migracji zarobkowej, operująca kategorią inwazji, nie wynika z reporterskiej pomysłowości, a cytuje interpretacje brytyjskiej prasy, reagującej na masowy napływ Polaków. Winnicka powołuje się na takie publikacje jak: How the Invasion of Immigrants into Every Corner of England Made a Mockery of PM's Promise to Close the Door (Jak inwazja imigrantów na każdy skrawek angielskiej ziemi zadrwiła z obietnicy parlamentarzystów, że zamkną przed nimi drzwi - opublikowane w „Daily Mail” z 31.03.2013 roku), The Polish Paradox (Polski paradoks - „The Economist” z 14.12.2013 roku), Mass Imigration Has Left Britain „Unrecognisable", Says Nigel Farage (Masowa imigracja zmieniła Wielką Brytanię nie do 
poznania, mówi Nigel Farage - „The Daily Telegraph” z 28.02.2014 roku) (zob. Winnicka 2014: 8). Słowem „angole” posługują się też w swoich wypowiedziach polscy zarobkowi podróżnicy w odniesieniu do gospodarzy kraju, w którym się znaleźli i których inność czy obcość pragną jakoś oswoić, pomniejszyć poprzez zastosowanie pogardliwej nazwy.

Tak więc nic tu nie jest neutralne. W przypadku migracji zarobkowej z Europy Środkowo-Wschodniej można by mówić o swoistej odmianie strefy kontaktu³ , czyli przestrzeni zetknięcia się różnych kultur, w której „geograficznie i historycznie odległe ludy [...] nawiązują relacje, wiążące się zazwyczaj z przymusem, sferą nierówności, trudnym do zażegnania konfliktem” (Pratt 2011: 26). Między Polakami a rodowitymi Anglikami wielkich różnic geograficznych nie ma, lecz już sam fakt bycia wyspiarzami sprawia, że rdzenni mieszkańcy Wielkiej Brytanii nie interesują się nadto Europą kontynentalną, bardzo niewiele wiedzą o jej części środkowo-wschodniej, a historycznymi doświadczeniami znacząco różnią się od Polaków. Migracja zarobkowa stawia przybyszów z Polski w roli petentów zmuszonych okolicznościami do podporządkowania się gospodarzom terenu, a więc choćby ze względu na rodowitość, naturalną znajomość języka i reguł życia społecznego na Wyspach - podmiotom dominującym.

Polscy angole 4 interpretują brytyjską rzeczywistość tak, jak podpowiada im polska mentalność ukształtowana historycznie, politycznie, obyczajowo przez polską szkołę, Kościół katolicki, przekazy mediów publicznych uwikłanych w spory polityczno-światopoglądowe polskiej części świata, a także środowisko sąsiedzko-rodzinne. Taki układ odniesienia kreuje własne wyobrażenie o ładzie zastanym na Wyspach i o miejscu, które polski przybysz zajmuje w tym porządku. Przy okazji zostaje zarysowany obraz „tubylca” - Anglika/Angola takiego, jaki się jawi przybyszom. Ten sam proces, tylko w odwrotną stronę, zachodzi w świadomości gospodarzy terenu, przykładających własne miary do (ustereotypizowanego) wizerunku środkowoeuropejskich migrantów.

Powtórzę, nic tu nie jest neutralne. Wszystko podszyte jest zaś emocjami i oglądane przez pryzmat habitusu ukształtowanego w innych warunkach niż obiekty rozpoznawane. Jak Brytyjczycy postrzegają polskich migrantów,

3 Chodzi o swoistą wersję strefy kontaktu, ponieważ doświadczenia migrantów zarobkowych w XxI wieku w sposób oczywisty różnią się od wrażeń metropolitalnych podróżników odwiedzających kolonie, a to o tych ostatnich okolicznościach pisała Pratt, używając terminu „strefa kontaktu”.

4 Taki zapis stosuję w odniesieniu do Polaków, którzy po wyjeździe zarobkowym do Wielkiej Brytanii musieli zaadaptować się do życia na Wyspach, a więc rozpoznać reguły funkcjonowania brytyjskiego społeczeństwa i odnieść się do nich tak, by co najmniej przetrwać w nowych warunkach. 
czytelnik reportażu Winnickiej nie dowiaduje się od nich samych, lecz pośrednie skąpe informacje na ten temat otrzymuje w wypowiedziach Polaków, których słucha autorka.

Jakkolwiek doświadczenie spotkania w tak ukształtowanej strefie kontaktu było ważne dla obu stron i przyniosło nie tylko pożądane skutki (choćby w postaci dostarczenia często demagogicznych argumentów zwolennikom brexitu), to relacje migrantów z zarobkowego wyjazdu na Wyspy znacznie więcej mówią o nich samych, o ich sposobie reagowania na nową rzeczywistość oraz jej interpretowania niż o czymkolwiek innym. Ujawnia się w nich taka strategia przedstawiania przez przybysza nowej dlań przestrzeni cywilizacyjno-historycznej i społeczno-kulturowej, poprzez którą mimowiednie przenika jego autoobraz ze wszystkimi wyznacznikami kondycji „gorszego” Europejczyka, co podskórnie musi rodzić resentymenty.

Ów materiał mówi o czymś jeszcze ważniejszym. Oto przez pryzmat doświadczeń polskich migrantów ekonomicznych w Wielkiej Brytanii można dostrzec zasadnicze problemy polskiej transformacji ustrojowo-gospodarczej w jej aspekcie ekonomicznym i kulturowo-obyczajowym, które w zderzeniu migracyjnych podmiotów (podporządkowanych, zmarginalizowanych) z nowym brytyjskim środowiskiem szybciej niż w kraju utraciły przezroczystość i nabrały cech dyskursywnych.

Nikt nie chce wieść „półżycia” ani stać się „półzwierzakiem”, skoro migrowało się po to, by poprawić własną sytuację materialną. Dlatego w relacjach polskich migrantów takie słowa pojawiają się w opowieściach o współrodakach, nie o sobie: „Ja wciąż widzę na ulicy zarówno porządną matkę z dzieckiem, jak i wyrwanego ze środka puszczy polskiego półzwierzaka z piwem w reklamówce. Bez respektu dla otoczenia" (Winnicka 2014: 118) - powiada Jurek z Londynu. „Ludzie przyjeżdżają i mówią, że to tylko na chwilę, do pracy, po co im język angielski albo zainteresowania. I siedzą latami w półżyciu” (Winnicka 2014: 147, wyróż. - H.G.) - dodaje Monika. Owo „pół-”, pojawiające się w charakterystyce Polaków, którym na Wyspach się nie powiodło, oznacza trwanie w stadium wegetacji i dowodzi, że przyjęte przez nich taktyki codziennych zachowań nie przyniosły oczekiwanych rezultatów w postaci odpowiednio wynagradzanej pracy.

Jak pisał Michel de Certeau, taktyka to czynność bez własnego miejsca, odbywająca się w obszarach, które należą do Innego, a więc aktywność przypominająca ruch wewnątrz pola widzenia wroga w przestrzeni przezeń kontrolowanej (de 
Certeau 2008: 37). Czynność podejmowana przez „słabych” w polu panowania porządku ustalonego przez „silnych”. Badacz proponował tę terminologię jako uniwersalną w odniesieniu do podmiotów wykonujących podstawowe czynności życiowe w rzeczywistości społecznej uporządkowanej przez władzę, dyktującą reguły społeczno-kulturowe akceptowane przez daną wspólnotę.

Polscy migranci w Wielkiej Brytanii, by osiągnąć swoje cele albo choć przetrwać, uprawiają, jeśli można tak powiedzieć, taktykę do kwadratu. Jako podmioty życia codziennego występujące w roli pracowników i konsumentów są „słabi” nie tylko w sensie nadanym temu określeniu przez de Certeau, ale też słabi ze względu na kondycję przybysza z zewnątrz, który - nim zacznie stosować własną grę z regułami ustanowionymi przez „silnego” - musi najpierw je poznać, a to bez satysfakcjonującej znajomości języka i regulowanej miejscowym prawem kultury życia społecznego jest niemożliwe lub bardzo trudne do osiągnięcia.

Jeden z rozmówców Winnickiej, który skutecznie zaadaptował się do warunków życia na Wyspach, powiada:

Zachód to nie jest bajka, dlatego trzeba lawirować [czyli stosować taktykę uwzględniającą różnice społeczno-kulturowe między przybyszem/podmiotem słabym i gospodarzem/podmiotem silnym - H.G.] między mentalnością Polaka i Anglika. Mówić a mówić to są dwie różne rzeczy. Mówić a czuć to są naprawdę dwie bardzo różne rzeczy. Polak nie jest w stanie wyrazić odczucia, opisać refleksji po angielsku. Angol zawsze będzie wiedział, że ja to ja, a on to on. Zawsze zostaniesz dla nich Polakiem (Winnicka 2014: 17).

Ostatnie stwierdzenie oznacza, że w optyce tego Polaka migrant nigdy nie wejdzie do społeczno-kulturowej wspólnoty gospodarzy Wysp. Rzeczywiście, kwestia przynależności do wspólnoty to zagadnienie granicy między swojskością i obcością. Badaczka tego problemu, Magdalena Pajor, zauważa:

Jeśli ktoś pyta o zasady przynależności, to znaczy, że ich nie spełnia, lecz jeśli ich nie spełnia, to nie dlatego że nie dostrzega ich istnienia [cytowany rozmówca Winnickiej wyraźnie je zauważa - H.G.], ale dlatego, że dostrzeganie istnienia tych zasad uniemożliwia ich spełnienie (Pajor 1999: 164-165).

I jeszcze jedno: 
Pytanie o przynależność do wspólnoty jest otwarciem przestrzeni, w której założona zostaje przeszłość, ale zarazem założona zostaje niemożliwość przeszłości. [...] Obcy nigdy nie przestanie być obcy; jeśli tylko przedstawi swą przeszłość, dowodzi tym samym swego związku z przeszłością, a [więc - H.G.] niemożności wejścia w przyszłości do wspólnoty (jego przeszłość ciąży nad jego współistnieniem we wspólnocie) (Pajor 1999: 168-169).

Nie wszyscy migranci zarobkowi zamierzali osiąść w Wielkiej Brytanii na stałe, lecz duża część z nich tam pozostała. Ci, którzy wybrali Wyspy, mniej lub bardziej świadomie zdefiniowali na własny użytek okoliczności, dla których polska przeszłość nie zamieniła się w ich przypadku w polską teraźniejszość ani w polską przyszłość. O polskich realiach mówi się tu najczęściej w poetyce zestawienia $\mathrm{z}$ różnymi od nich realiami brytyjskimi i bywa, że porównanie wypada na korzyść tych drugich. Chodzi o przyjazny stosunek brytyjskich instytucji państwowych do obywatela, widoczne efekty równouprawnienia osób niepełnosprawnych, ochronę kobiet i dzieci, która w patriarchalnej, konserwatywnej, nominalnie wysoko ceniącej rodzinę Polsce XxI wieku pozostawia wiele do życzenia.

Jurek z Londynu podkreśla, że „przemoc i alkohol to pięta achillesowa społeczności polskiej” (Winnicka 2014: 120). W Wielkiej Brytanii przemoc wobec kobiet i dzieci jest zaś surowo karana, ale - jak przyznaje - „Polacy się szybko uczą nowego prawa. Na pewno nie biją [dzieci - H.G.] po plecach i po nóżkach, żeby nie było widocznych śladów" (Winnicka 2014: 122). To szczególny sposób przyswojenia reguł obowiązujących w nowej rzeczywistości, w której dochodzą do głosu stare nawyki.

Ważne w wypowiedziach migrantów wydają się przemilczenia czy niedomówienia na temat polskiej transformacyjnej codzienności, która była przyczyną wyjazdu z kraju w poszukiwaniu czegoś lepszego. Owa cisza lub tylko skąpe napomknienia zdają się wskazywać na istnienie trudno dostrzegalnych źródeł traumy, której część tych ludzi zaznała w Polsce. Traumy szczególnej ze względu na swój powszedni, ciągły, normatywny charakter (zob. Craps 2015: 417-443) związanej z codziennością podmiotów w jakimś stopniu pozbawionych władzy nad własnym losem, mieszkańców wsi czy miasteczek, którzy nie zyskali na transformacji, a doznali swoistej przemocy wykluczenia czy stygmatyzacji jako nieudacznicy. Nie chodzi tu więc o traumę jako efekt pojedynczego wstrząsającego zdarzenia, lecz o chroniczne cierpienie spowodowane okolicznościami natury społeczno-ekonomicznej i brakiem nadziei na realną zmianę warunków życia. W niektórych przypadkach ta sytuacja dotyczy egzystencji migranta 
zarówno minionej, tj. polskiej, jak i aktualnej, brytyjskiej. Janek z Londynu mówi o takiej prawidłowości:

Człowiek przyjeżdża do pracy w Anglii nieprzygotowany, żyje z dnia na dzień. A jeżeli traci pracę, to nie może zapłacić za wynajem mieszkania. Jak nie zapłaci za dwa tygodnie, to musi się wyprowadzić na bruk. Jeżeli nie ma żelaznej rezerwy, żeby przeżyć miesiąc i znaleźć pracę, to zostaje bezdomnym. Wstydzi się wracać do Polski, dostaje depresji. I targa się na życie (Winnicka 2014: 143).

O traumatyzującej brytyjskiej codzienności ludzi podwójnie podporządkowanych, bo uważanych za „gorszych” Europejczyków i do tego nieznających w wystarczającym stopniu języka angielskiego, opowiadają też liczni autorzy powieści o polskim życiu na Wyspach napisanych po 2004 roku (zob. Dąbrowski 2016: 300-332 oraz numer monograficzny „Tekstów Drugich” z 2016 roku). Te stosunkowo proste narracje, przeważnie wykorzystujące klisze literatury popularnej, wydają się lokować poza ramami estetyki traumy, którą badacze tego zjawiska zwykli wiązać z formami antynarracyjnymi, nielinearnymi, fragmentarycznymi, a więc z zakłóceniami konwencjonalnych sposobów przedstawiania, które dają o sobie znać w sztuce modernistycznej. Tymczasem w obszarach pozaeuropejskich - których realia często nie są zbyt odległe od realiów peryferyjnych krajów Europy, do których należy Polska - panuje przekonanie, iż trauma niekoniecznie sygnalizuje swoją obecność tekstami antynarracyjnymi. Jak zauważa Roger Luckhurst, problemy wywołane traumą rodzą zarówno niemożliwość, jak i możliwość narracji. Ta druga opcja korzysta $\mathrm{z}$ „wysokich, średnich i niskich form kultury, które tworzą [...] repertuar środków artykulacji tego z pozoru paradoksalnego zjawiska, jakim jest narracja traumy” (cyt. za: Craps 2015: 429). Stef Craps dodaje, że Luckhurst opiera te rozpoznania na analizie literackich przykładów wspomnianej problematyki, na które natrafił, „badając popularne pamiętniki i powieści związane z traumą” (Craps 2015: 429).

Jeśli „popularne pamiętniki” mogą przekazywać doświadczenie traumy, na przykład traumy kapilarnej, związanej z beznadziejną, odbieraną jako opresyjna codziennością, to zgrzebne literacko powieści o życiu Polaków na Wyspach i rozmowy z nimi zawarte w reportażowej książce Winnickiej również stają się przekaźnikiem tego doświadczenia. Decyzja o migracji zarobkowej wielu Polaków została wywołana przez krajową rzeczywistość transformacyjną, która jawiła się im po części jako groźna, pozbawiająca znanych punktów oparcia i źródeł pewności, a po części wykluczająca ze względu na stawiane wymagania. W ujęciu Przemysława Czaplińskiego ta z obawami przyjmowana 
transformacja rysowała się wielu następująco: „narodowość, płeć, tradycyjna obyczajowość, przyzwoitość, religijność zostają wyparte przez antynarodowe tendencje globalizmu, przez emancypację mniejszości, zrównanie tożsamości seksualnych i duchowość newage’ową" (Czapliński 2009: 58), a dziki kapitalizm pozbawia środków do życia i każe ludziom wstydzić się własnej nieporadności.

Polscy angole spotkali na Wyspach takie właśnie wymiary kapitalistycznej normalności, które w Polsce zaczęły dopiero się ujawniać w latach dziewięćdziesiątych xx wieku i okazały się trudne do zaakceptowania dla dużej części społeczeństwa, bowiem, jak pisał autor Polski do wymiany..., zmuszały do przebudowy „całego «porządku naturalnego», jaki trwał przez kilkadziesiąt [wcześniejszych - H.G.] lat” (Czapliński 2009: 317). Na ten porządek składały się m.in. nawyki wyuczone w PRL-u, a dotyczące nieufności w relacjach obywatel instytucje państwa czy znaturalizowane przeświadczenie o podrzędnym miejscu kobiety w życiu społecznym z jego patriarchalnym modelem rodziny. Do tego porządku należała też obawa przed Obcymi, których zwykło się separować od polskiej wspólnoty (jak Żydów, Niemców, Rosjan) lub poniżać, jeśli okazywali się pod jakimś względem słabsi (Ukraińcy, osoby nieheteronormatywnes).

System prawny na Wyspach, choć przecież niedoskonały, okazał się obliczony na wspomaganie obywatela w trudnych sytuacjach, np. gdy ten bywa wykorzystywany przez pracodawcę. Migranci teoretycznie mogli się do prawa odwoływać. Jeden z nich, rozmawiając z Winnicką, pyta retorycznie: „jak Polacy mają skorzystać z paragrafu, kiedy się boją zadzwonić do przyjaznego councilu?" I konstatuje: „Jesteśmy narodem zastraszonym i niedouczonym” (Winnicka 2014: 120, wyróż. - H.G.). A nawet gorzej - między rodakami na Wyspach brak solidarności: „wrogiem nierozgarniętego Polaka za granicą nie jest obcokrajowiec, tylko rodak, zwłaszcza mówiący po angielsku" (Winnicka 2014: 120). Tak sformułowana diagnoza o braku więzi społecznych między rodakami dotyczy Polaków w ogóle, nie tylko tych, którzy chcieli poprawić swój byt poprzez migrację zarobkową. Rzecz objawiła się wyraźnie w zderzeniu z brytyjską codziennością, lecz definiowała przede wszystkim realia polskie

5 Jedna z rozmów Winnickiej dotyczy zakończonych porażką starań Polki-lesbijki o wyrobienie w Polsce aktu urodzenia córki wychowywanej z angielską partnerką. Kasia z Londynu tak opowiada o swojej nieheteronormatywnej rodzinie: „Mieszkamy na prywatnej ulicy i sąsiedzi okazują radość na nasz widok. Czy mówią coś za naszymi plecami? Wątpię. [...] Urodziłam się w robotniczym mieście, miałam braci bliźniaków oraz mamusię i tatusia. Klasyczną rodziną byliśmy. Odkąd pamiętam, rodzice chodzili pijani. Zapili się na śmierć i moi bracia też już nie żyją. Nie chcę więcej słuchać o tradycyjnych rodzinach" (Winnicka 2014: 213-214). 
$\mathrm{z}$ ich brakiem wspomnianych więzi, wspieraniem się jedynie w wąskich grupach sąsiedzko-rodzinnych, a i to nie zawsze.

$\mathrm{Na}$ realia polskie składa się też fakt, że migracja zarobkowa po roku 2004 była kolejną falą wyjazdów z ojczyzny po tych politycznych - wojennej, marcowej 1968 roku czy solidarnościowej lat osiemdziesiątych. Polacy, którzy opuścili kraj w różnych czasach, okolicznościach i z różnych przyczyn, albo żyli w gettach narodowościowych, albo przeciwnie - stronili od siebie w Wielkiej Brytanii. W opowieści Bożeny ze Scunthorpe pojawia się taka scena z kościoła:

Do nowej salki parafialnej nie przychodzili nigdy emigranci polscy z czasów wojny. W kościele trzymali się osobno. Bardzo eleganccy, można ich było dojrzeć w prawej nawie. Wyróżniali się na tle młodych nowo przybyłych, a na ich twarzach rysowało się rozczarowanie, że ta nowa fala nie jest zbyt elegancka (Winnicka 2014: 261, wyróż. - H.G.).

„Zastraszony i niedouczony” migrant z dużym trudem radzi sobie z rozmaitymi odmianami obcości (albo w ogóle sobie z nimi nie radzi i próbuje odtwarzać sposoby życia, które stosował w polskiej przeszłości, co jedynie umacnia jego obcość). Problemy się mnożą, począwszy od języka, który słabo rozumie, więc sądzi, że komunikaty czy dokumenty w nim sformułowane go nie dotyczą, po różnice kulturowe, które każą mu jeść to, do czego przywykł w Polsce ${ }^{6}$, i spędzać czas tak jak w Polsce, choćby wtedy gdy jest starszą kobietą z małego miasta. W kraju wiele takich kobiet często bywa w kościele.

Toteż pięćdziesięciosześcioletnia polska migrantka ponad siły pracująca w Anglii wyzna: „Przy życiu trzymała mnie perspektywa weekendu. Najpierw modlitwa i spotkania z kilkorgiem Polaków, zrzeszonych w przykościelnej wspólnocie. [...] Gdziekolwiek się Polak za granicą znajdzie, powinien się trzymać Boga. Wtedy zostanie w pionie" (Winnicka 2014: 259, 261). A, jak twierdzi Romek z Londynu, jeszcze wiele starań trzeba dołożyć, by niejako wbrew sobie na co dzień przyznawać, że „szklanka [jest - H.G.] zawsze do połowy pełna, a nie pusta” (Winnicka 2014: 44), ponieważ, zdaniem Moniki z Henley: „Nienarzekanie jest tutaj obowiązkowym kodem” (Winnicka 2014: 112), gdy jak uważa Wojciech z Londynu - „my [Polacy - H.G.] wypijamy z mlekiem rodziców negatywne podejście” (Winnicka 2014: 18). Te spostrzeżenia zawarte w krótkich, sygnalnych zdaniach prezentują zestaw charakterystycznych różnic w mentalności polskich przybyszów i brytyjskich gospodarzy Wysp.

6 „Nie potrafię robić zakupów jak Angole, nie wiem, co jest dobre, jak się przyprawia, więc staram się jeść jak w Polsce” (Winnicka 2014: 220) - przyznaje Justyna z Bolton. 
Wszyscy rozmówcy Winnickiej, którzy zostali na Wyspach, opisują swoje bardziej lub mniej udane próby włączenia się do społeczno-kulturowego świata Brytyjczyków, a więc definiują się wobec niego jako Obcy. Obcy są obserwowani, lecz sami również obserwują. Szybko wychwytują, czym różnią się od rodowitych Brytyjczyków. Po pierwsze, dostrzegają angielski dystans w słowach i zachowaniach. Piotr z Londynu mówi: „Anglicy są do bólu poprawni politycznie i ci w życiu nie powiedzą, że nie lubią Greków albo Jamajczyków” (Winnicka 2014: 163). Ale Marcin z Manchesteru konstatuje sobie właściwym językiem: „[... jak jeden ciapaty zajmuje dom, to za chwilę już żaden Anglik nie chce kupić domu obok, więc się cała dzielnica robi ciapata" (Winnicka 2014:122). Lidia ze Stockton-on-Tees żali się zaś: „Od roku nie potrafię się zaprzyjaźnić z żadnym z pracujących tu Angoli. Boli mnie powierzchowność” (Winnicka 2014: 186).

Po drugie, Obcy odkrywają, że Wyspiarze to zbiorowość wewnętrznie mocno zhierarchizowana. Są wśród nich tacy, którzy żyją na zasiłku i z pewnością nie ukończyli elitarnych szkół (podobnie jak polscy migranci), a także członkowie klasy wyższej, którzy tych pierwszych traktują jak powietrze. Kamil z Londynu zauważa więc: „typowa Angielka: duża, farbowane włosy, papieros w ustach i szaro-różowy dres. Żyje na benefitach" (Winnicka 2014: 160), Artur z Manchesteru dodaje zaś: „Nigdy bym nie chciał Angielki. One więcej życia spędzają w pubie" (Winnicka 2014: 233), a Rafał z Edynburga powiada:

Obcokrajowcy oraz Anglicy, którzy nie kończą [...] [elitarnej - H.G.] szkoły, należą do podspołeczeństwa, z którym nie można się specjalnie zadawać, dla jego własnego dobra. [...] Dla angielskich dziewczyn jako obcokrajowiec byłem niewidzialny (Winnicka 2014: 27, 29, wyróż. - H.G.).

Jakie wnioski płyną z tych obserwacji? Oto na przykład Romek z Londynu przyznaje: „Musiałem się zapoznać z kodem kulturowym w biznesie doradczym, a następnie szybko go przyswoić” (Winnicka 2014: 44, wyróż. - H.G.). Wniosek Marcina z Manchesteru brzmi: „Żeby się zintegrować należy spełnić kilka warunków. [...] Anglik musi najpierw zaufać, że jesteś po jego stronie” (Winnicka 2014: 196, wyróż. - H.G.). Można też tak jak Wojciech, właściciel firmy sprzątającej z Londynu, który stwierdza: „Żeby posprzątać [...] trzeba mieć system. Sam go opracowałem i stałem się specjalistą. System polega na tym, żeby sprzątać nie wyżej jak na wysokości oczu oraz stosować triki na klienta. Znaczy posprzątać przed drzwiami i wytrzeć klamkę" (Winnicka 2014: 16, wyróż. - H.G.).

De Certeau rozpoznałby tu taktyki podmiotów słabych, „kłusujących” na terenie zagospodarowanym przez podmioty silne - odkryć kod, uwzględnić go we 
własnym systemie działania i korzystnie zastosować wobec gospodarzy terenu, by zrealizować własny cel. Pozycja Obcego nie jest komfortowa, lecz Romki, Marciny, Wojtki uważają, że jeśli przechwycić jej wyznaczniki i zredefiniować tak, by stały się orężem w batalii o poprawienie własnego bytu, to wykreuje się nową jakość - kulturową wspólnotę Innych o hybrydycznej tożsamości.

Gdyby skorzystać z myśli Bernharda Waldenfelsa, rozważającego warunki, w których podmiot czuje się obco lub sam desygnuje Obcych, a więc znajduje się w sferze dyskomfortu albo komfortu egzystencjalno-aksjologicznego, należałoby przyjąć, iż zależy to od tego, gdzie umieszcza się miarę normalności/akceptowalnej swojskości - w świecie własnym (tu: polskich Swojaków) czy też w świecie innych (tu: rodowitych mieszkańców Wysp Brytyjskich). Ze spostrzeżeń autora Topografii obcego... wynika, iż w pierwszym przypadku to Ja polskiego migranta decydowałoby, co mieści się w normie; $\mathrm{w}$ drugim owo Ja podlegałoby presji zewnętrznych, ważnych powinności, których nieprzestrzeganie rodzi dyskomfort i naraża na represje, a zachowanie nieprzestrzegającego zasad podmiotu jawi się wówczas jako anomalia, odstępstwo od tego, co normalne/akceptowane. Jednym słowem, poczucie komfortu pojawia się lub nie w zależności od tego, gdzie podmiot dostrzega źródło prawomocnego autorytetu w kwestii normalności - w sobie czy na zewnątrz (Waldenfels 2002: 41).

Niechętny stosunek części Brytyjczyków wobec napływu taniej siły roboczej z Europy Środkowo-Wschodniej, wykorzystany przez populistycznych polityków jako jeden $z$ argumentów skłaniających do brexitu, ostatecznie doprowadził, jak wiadomo, do wyjścia Wielkiej Brytanii z Unii Europejskiej i zaostrzenia przepisów migracyjnych. Literatura dotycząca zjawiska polskiej migracji zarobkowej na Wyspy (w tym również reportażowa) diagnozowała symptomy kryzysu i ukazywała go jako wypadkową procesów o szerszym zakresie, m.in. lęków zrodzonych przez globalizację niosącą zmiany i zmuszającą do korygowania oswojonych porządków, uznawanych wcześniej za bezpieczne, a w pierwszej dekadzie XXI wieku potraktowanych jako stawka w grze egoizmów narodowych.

Ci z polskich migrantów poakcesyjnych, którzy osiedli na Wyspach, mieli do wyboru któryś z dwu wzorców relacji z Brytyjczykami: albo tkwić w hermetycznej społeczności polskich angoli, pokonanych przez niedostępność obcego języka, negatywne stereotypy, wrogość części Brytyjczyków nieskłonnych do akceptowania niewspółmierności kulturowych, albo wypracować nową, hybrydyczną tożsamość polsko-angielską i pogodzić się z jej istotą, którą stanowi 
różnica kulturowa. Pozostają jeszcze ci, którzy wrócili do kraju z poczuciem klęski, zawodu, rozczarowania, wstydu. Oni też, jak wszyscy migranci, byli zmuszeni zmierzyć się z problemem własnej i cudzej tożsamości narodowej’.

Rozmówcy Winnickiej oraz im podobni zarobkowi podróżnicy intuicyjnie wyczuwają lub po prostu wiedzą, kim się stali w Wielkiej Brytanii, a także w przeżywającej posttransformacyjne, populistyczno-nacjonalistyczne wzmożenie Polsce - oto są Kimś Innym niż wcześniej. Relacje polskich migrantów zebrane w reportażowym tomie tej autorki stały się przykładowym materiałem dla moich refleksji właśnie dlatego, że ani nie prezentują prostej krytyki społeczeństwa brytyjskiego, ani nie zostały przedstawione jako słuszne. Wydaje się, iż sygnalizują ważne problemy charakterystyczne dla naszego czasu historycznego, a więc mogą być rozpatrywane w kategoriach materiału diagnozującego zyski i straty wynikające ze spotkań „Swojaków” z „Obcymi”. Cudzysłów sygnalizuje tu nieoczywistość, relatywność owych terminów zależną od okoliczności.

Jeśli polski migrant dowiedział się, że jest Kimś Innym niż wcześniej, to Brytyjczycy też mogą mówić o specyficznym zysku płynącym ze spotkania z migrantami, gdybyśmy za taki uznali zwiększenie spójności wyspiarskiej tożsamości, jej zdolności do autodefiniowania się jako wspólnota. Wystarczy przypomnieć konstatację Pierre’a Bourdieu o tym, że:

tworzony przez ludzi „wspólny świat” polega w podwójnym tego słowa znaczeniu na wykluczeniach. Polega na wykluczeniach, ponieważ jego uspójniająca zasada może się ukonstytuować jedynie wobec tego, co pozostaje na zewnątrz [tu: wobec przybyszów z Europy Środkowo-Wschodniej - H.G.]. I polega na wykluczeniach, ponieważ to pozbawieniu mowy wykluczonych zawdzięcza swoją wspólność (Jacyno 1999: 49).

Brexit, ograniczający migrację zarobkową z jej głosem, to swego rodzaju instrument wykluczenia.

7 Jeśli w sprzyjających warunkach uda się wziąć w nawias cały problem relatywnej obcości i tożsamości narodowej, można powiedzieć po prostu tak, jak Joanna z Londynu: „Dobrze się czuję, a czy jestem Polką, to już dawno przestałam się nad tym zastanawiać" (Winnicka 2014: 94, wyróż. - H.G.). Albo, wprost przeciwnie - jak bohater prozy Marka Kazmierskiego Damn the Source (2013) - „Nigdy nie myślałem o sobie jako o Polaku - aż przyjechałem tutaj i się przekonałem, że wszyscy inni tak o mnie myślą" (cyt. za: Dobrogoszcz 2016: 57, wyróż. - H.G.). 
Wspólnota zwykle aktywizuje się, by rozwiązać problem Obcych. Owo działanie nieodwracalnie zmienia ją samą. Po gromadnym pojawieniu się polskich migrantów zarobkowych jakaś część brytyjskiej rzeczywistości zmobilizowała się, by dać odpór temu zjawisku, co prowadziło do ujawnienia konstytuujących ją porządków oraz ich modyfikacji. Dzięki (na swój sposób) interwencyjnemu charakterowi obecności migrantów z Europy Środkowo-Wschodniej Brytyjczycy doświadczyli potrzeby utwierdzenia swojej identyczności (choć nie był to oczywiście jedyny powód rozbudzenia tej potrzeby). By ją zaspokoić, ostatecznie zdecydowali się na brexit.

Zdając sobie sprawę $\mathrm{z}$ faktu, że to tylko pewien etap w relacjach Brytyjczyków z migrantami z Europy Środkowo-Wschodniej czy w ogóle z Europą kontynentalną, można by przywołać refleksję Emmanuela Lévinasa o tym, że spotkanie z Innym/Obcym to swoista wersja relacji z przyszłością, jeśli pamiętać, że przyszłość sama w sobie jest czymś innym/obcym. A więc to relacja nieunikniona. Ludzka podmiotowość (jednostkowa i zbiorowa) bezustannie trwa w kontakcie z Innym, który staje się warunkiem jej istnienia. Pojawia się tylko pytanie, czy wytwarza również po obu stronach odpowiednio silny impuls do podjęcia odpowiedzialności za owo współbycie.

\section{| Bibliografia}

Certeau Michel de (2008), Wynaleźć codzienność. Sztuki działania, przeł. Katarzyna Thiel-Jańczuk, Wydawnictwo Uniwersytetu Jagiellońskiego, Kraków.

Craps Stef (2015), Poza eurocentryzm. Teoria traumy w epoce globalizacji, przeł. Jan Burzyński, w: Antologia studiów nad traumą, red. Tomasz Łysak, Universitas, Kraków, s. 417-443.

Czapliński Przemysław (2009), Polska do wymiany. Późna nowoczesność i nasze wielkie narracje, W.A.B., Warszawa.

Dąbrowski Mieczysław, (2016), Życie na Wyspach, w: tenże, Tekst międzykulturowy. O przemianach literatury emigracyjnej, Elipsa, Warszawa, s. 300-332.

Dobrogoszcz Tomasz (2016), Przeciw stereotypom: mimikra a hybrydyczność. Wspótczesna proza polska na tropie tożsamości polskich migrantów wielkiej Brytanii, „Teksty Drugie”, nr 3, s. 42-59.

Douglas Mary (2007), Czystość i zmaza, przeł. Marta Bucholc, PIw, Warszawa. Jacyno Małgorzata (1999), Iluzje codzienności. O teorii socjologicznej Pierre’a Bourdieu, Wydawnictwo IFiS pan, Warszawa. 
Kornhauser Julian (1978), Zjadacze kartofli, https://tinyurl.com/4rkazgrv [dostęp: 18.01.2021].

Luckhurst Roger (2008), The Trauma Question, Routledge, London.

Pajor Magdalena (1999), Przemoc jako kategoria filozoficzno-artystyczna, „Sztuka

i Filozofia", nr 17, s. 162-174.

Pratt Mary Louise (2011), Imperialne spojrzenie. Pisarstwo podróżnicze

a transkulturacja, przeł. Ewa Elżbieta Nowakowska, Wydawnictwo

Uniwersytetu Jagiellońskiego, Kraków.

Waldenfels Bernhard (2002), Topografia obcego. Studia $z$ fenomenologii obcego,

przeł. Janusz Sidorek, Oficyna Naukowa, Warszawa.

Winnicka Ewa (2014), Angole, Wydawnictwo Czarne, Wołowiec.

\section{| Abstrakt}

HANNA Gosk

Zjadacze łabędzi. Obcość relatywna w doświadczeniu polskiej migracji ekonomicznej do Wielkiej Brytanii po roku 2004

Tekst włącza się w dyskusję o ruchach migracyjnych, aktualizujących kwestię podziałów społeczno-kulturowych także między społeczeństwami europejskimi o silnie ukształtowanych (a dodatkowo wewnętrznie zróżnicowanych) tożsamościach zbiorowych. Stawia tezę, że analizując doświadczenia polskich migrantów ekonomicznych w Wielkiej Brytanii, można też dostrzec zasadnicze problemy polskiej transformacji ustrojowo-gospodarczej w jej aspekcie społeczno-kulturowym, które w zderzeniu migracyjnych podmiotów (podporządkowanych, zmarginalizowanych) z nowym środowiskiem szybciej niż w kraju utraciły przezroczystość i nabrały cech dyskursywnych.

Wywód koncentruje uwagę na spotkaniu polskiego Swojaka (przeciętnej jednostki, uosabiającej polską peryferyjną wersję normy cywilizacyjno-kulturowej, która wyraźnie separuje Swoich od Obcych) z sytuacją, w której ów Swojak sam zajmuje, jako migrant, pozycję Obcego. Przykładowego materiału do rozważań dostarcza tom reportaży Ewy Winnickiej Angole (2014). W warunkach, w których kondycja polskiego migranta bywa przezeń (często) mimowiednie problematyzowana, podmiot taki dokonuje autoobserwacji oraz próbuje (z różnym skutkiem) odnaleźć się w relacji do miejscowych brytyjskich Swojaków, a więc źródła normy, wobec której, jako przybysz, sytuuje się na zewnątrz. Ma przy tym do dyspozycji głównie instrumenty, które - uwewnętrzniona przezeń, a powstała w innych warunkach - polska norma przewiduje do użycia w relacji z Obcym. 
Paradoksalność tych okoliczności, poza wszystkim innym, daje asumpt populistycznej instrumentalizacji generowanych przez nie zjawisk, co skutecznie wykorzystali zwolennicy brexitu.

Słowa kluczowe: migracja zarobkowa; swojskość; obcość; kod społeczno-kulturowy; polscy migranci; Ewa Winnicka Angole

\section{| Abstract \\ HanNA Gosk \\ Swan-Eaters: Relative Otherness in the Experience of the Polish Economic Migration to Great Britain After 2004}

The text joins a discussion about migration movements, calling to attention the issue of socio-cultural divisions occurring also between European societies whose collective identities are both strong and, additionally, internally diverse. The article claims that, by analysing the experience of Polish economic migrants to Great Britain, we can notice key problems of the Polish system and economic transformation in its socio-cultural aspects. These problems, much sooner than in Poland, lost their transparency and became discursive due to the clash of the immigrant (subaltern) subjects with the new environment.

The argument focuses on how the Polish familiar subject (an average individual, embodying the Polish peripheral version of the civilizational-cultural norm which distinctively separates Us [the familiar] from the Other [strangers]) experiences a situation in which the Familiar Pole takes on the role of the Other. Ewa Winnicka's Angole (2014) will serve as focal point of our discussion. As the condition of the Polish migrants often happens to be unintentionally problematized, the subject in question engages in self-observation and tries, with varying results, to find himself in a relation to the local British Familiars. In this structure, the latter become the source of the norm, in relation to which the Polish migrant situates himself on the outside. At the same time, the only available instruments are those that the Polish norm ascribes for use in relation with the Other.

The paradox of these circumstances, apart from anything else, gives way to the populist instrumentalization of the phenomena they generate, which was very effectively used by Brexit supporters.

Keywords: economic migration; familiarity; otherness; socio-cultural code; Polish migrants; Angole by Ewa Winnicka 


\section{| Biogram}

Hanna Gosk - prof. zw. w Zakładzie Literatury xx i xxı wieku na Wydziale Polonistyki Uniwersytetu Warszawskiego. Kieruje Pracownią Antropologicznych Problemów Literatury i Centrum Badań Dyskursów Postzależnościowych. Zajmuje się prozą i krytyką literacką, problematyką zmian zachodzących w literaturze polskiej po roku 1989, literackim obrazowaniem historii oraz ujęciami antropologicznymi, postkolonialnymi/postzależnościowymi w badaniach literackich. Autorka i redaktorka licznych książek naukowych. Ostatnio opublikowała Przemoc (w) opowieści. Ze studiów postzależnościowych nad literatura polska Xx $i$ XXI wieku (2019), Po transformacji? Literackie idiomy zjawisk i procesów rzeczywistości III Rzeczypospolitej (red. wraz z Ł. Pawłowskim, 2020).

E-mail: h.gosk@uw.edu.pl

ORCID: 0OOO-0O02-9336-6989 